Jiri Dvoracek

\title{
The Son of David in Matthew's Gospel in the Light of the Solomon as Exorcist Tradition
}

[Der Sohn Davids im Matthäusevangelium im Lichte der Salomo-als-Exorzist-Tradition.]

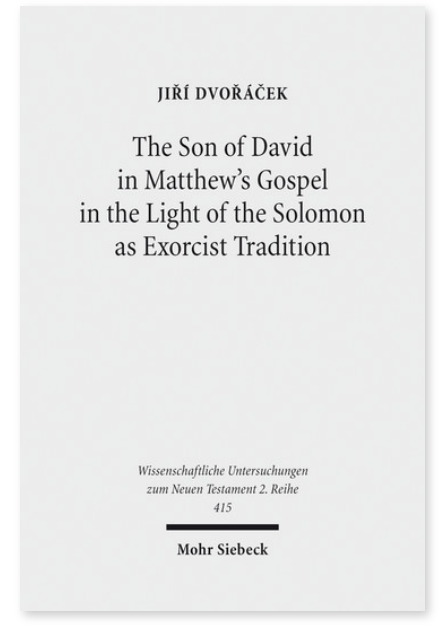

2016. XII, 258 Seiten. WUNT II 415

ISBN 978-3-16-154095-0

DOI 10.1628/978-3-16-154095-0

eBook PDF $94,00 €$

ISBN 978-3-16-154094-3

fadengeheftete Broschur 94,00€
Veröffentlicht auf Englisch.

Jiř́ Dvořáček untersucht in dieser Studie den Titel »Davidsohn« im Matthäusevangelium. Das matthäische Bild des heilenden Davidsohnes muss seiner Meinung nach auf dem Hintergrund der zeitgenössischen jüdischen Traditionen verstanden werden, insbesondere im Kontext der Salomo-als-Exorzist-Tradition. Zunächst analysiert der Autor die wichtigsten DavidsohnTexte, um zu zeigen, dass im 1. Jh. n. Chr. mit dem Titel »Davidsohn« nicht nur der königliche davidische Messias gemeint war, sondern auch Davids Sohn Salomo, dem exorzistische Kräfte und magisches Wissen zugeschrieben wurden. Danach zeigt Jiří Dvořáček an der Exegese der matthäischen Perikopen, wie Matthäus die königliche messianische Tradition mit der Salomoals-Exorzist-Tradition kombinierte, um ein Bild des barmherzigen, messianischen, heilenden Königs, des Sohnes Davids, zu schaffen, der in seiner Weisheit, seinen Heilungen und Exorzismen sogar den Davidsohn Salomo übertrifft.

Jiri Dvoracek Born 1980; 2004 MA, 2008 PhD at the Protestant Theological Faculty, Charles University of Prague and at the Faculty of Theology of the University of Bern; 2008-10 Vicariate in the Evangelical Reformed Churches of the Canton Bern-JuraSolothurn; 2010-11 Pastor in the Reformed Church of the Canton Fribourg, 2011-13 Bern and since 2014 Zurich.

Jetzt bestellen:

https://mohrsiebeck.com/buch/the-son-of-david-in-matthews-gospel-in-the-light-of-the-solomon-as-exorcist-tradition9783161540950?no_cache $=1$

order@mohrsiebeck.com

Telefon: +49 (0)7071-923-17

Telefax: +49(0)7071-51104 